\title{
BARTHEL INDEX SCORE IN STROKE PATIENTS INCREASES AFTER UNDERGOING MEDICAL REHABILITATION
}

\author{
Sirly Nabireta Maharani Ganing ${ }^{1}$, Imam Subadi², Paulus Sugianto ${ }^{3}$ \\ ${ }^{1}$ Student of Medical Education Program, ${ }^{2}$ Department of Physical Medicine and Rehabilitation, \\ ${ }^{3}$ Department of Neurology, Faculty of Medicine, Universitas Airlangga, Surabaya
}

\begin{abstract}
ABSTRAK
Stroke adalah penyebab utama kematian di kalangan masyarakat Indonesia yang berusia di atas lima tahun, terdiri dari 15,4\% dari semua kematian, dengan angka kematian sebesar 99/100 000, dan jumlah kecacatan 685/100 000. Rehabilitasi medis memiliki efek dalam meningkatkan status fungsional pasien dengan stroke, terutama jika hal tersebut dilakukan secara intensif dalam 6 bulan pertama setelah serangan stroke. Pengukuran status fungsional umumnya digunakan dalam klinik, termasuk di Rumah Sakit Dr. Soetomo. Namun, belum ada penelitian yang dilakukan untuk mengukur status fungsional menggunakan Indeks Barthel di Surabaya. Oleh karena itu, penelitian ini mengidentifikasi perbedaan status fungsional pasien stroke sebelum dan setelah menjalani rehabilitasi medis. Penelitian ini menggunakan metode eksperimen dengan desain pre dan post menggunakan total sampling. Sampel terdiri atas 47 pasien stroke di Rumah Sakit Dr. Soetomo, Surabaya. Data diperoleh antara Maret - April 2014 menggunakan Indeks Barthel. Analisis data yang digunakan adalah uji Wilcoxon Sign Rank, termasuk distribusi dari setiap variabel, yang menunjukkan nilai signifikansi <0,05. Penelitian ini menyimpulkan bahwa skor Indeks Barthel meningkat setelah menjalani rehabilitasi medis.
\end{abstract}

Kata kunci: status fungsional, stroke, Indeks Barthel

\begin{abstract}
Stroke is the leading cause of death among Indonesian people over the age of five years, comprising $15.4 \%$ of all deaths, with a mortality rate of 99/100 000, and the number of disability is 685/100 000. Medical rehabilitation has an effect in improving functional status of patients with stroke, especially if it is done intensively in the first 6 months after stroke attack. Measurement of functional status is commonly used in clinic, including in Dr. Soetomo Hospital. However, no study had been conducted in measuring functional status using Barthel Index in Surabaya. Therefore, this study identified the difference of the functional status of stroke patients before and after undergoing medical rehabilitation. The study used an experimental method with pre and post design with total sampling. The samples were 47 stroke patients in Dr. Soetomo Hospital, Surabaya. Data were obtained from March - April 2014 using Barthel Index. Data analysis used Wilcoxon Sign Rank test, including the distribution of each variable, which showed signification value of $<0.05$. This study concluded that Barthel Index score increases after undergoing medical rehabilitation.
\end{abstract}

Keywords: functional status, stroke, Barthel Index

Correspondence: Sirly Nabireta Maharani Ganing, Medical Doctor Program, Faculty of Medicine, Universitas Airlangga, Surabaya. Email: sirlynabireta@gmail.com

\section{INTRODUCTION}

Stroke is the leading cause of death among Indonesian people over the age of five years, $15.4 \%$ of all deaths, with a mortality rate of $99 / 100000$, and the number of disability 685/100 000. With subarachnoid hemorrhage percentage of $1.4 \%$ of patients, intracerebral hemorrhage was $18.5 \%$, and ischemic stroke by $42.9 \%$. The average age of stroke patients was 58.8 years old (Kusuma et al 2009). Stroke is the leading cause functional impairment, with $20 \%$ of victims who require institutional care after 3 months and $15 \%$ to $30 \%$ permanent disability (Goldstein et al 2011).

Medical rehabilitation had an effect in improving functional status of patients with stroke, especially if it is done intensively in the first 6 months. The more frequent medical rehabilitation, or the greater the intensity of medical rehabilitation time, the greater the improvement of functional status in stroke patients. Activation of neural networks is use-dependent, more it is used, the stronger and more synapses are formed (Bruno-Petrina 2007). However, no study about Barthel Index has been done in Surabaya, therefore the aim of this study will be conducted to determine the functional status of stroke patients before and after undergoing medical rehabilitation in Dr. Soetomo General Hospital, Surabaya by measuring the Barthel Index score before and after undergoing medical rehabilitation. 


\section{MATERIALS AND METHODS}

This study used an experimental method, pre and post design with total sampling using all of stroke patients at Neurology Department of Dr. Soetomo General Hospital Surabaya from 14th March to 30th April 2014 which includes meet the inclusion and exclusion criteria. The inclusion criteria of this research were an acute stroke patient, who was willingly join this research, would undergo medical rehabilitation in Dr. Soetomo General Hospital Surabaya only until it finished, with GCS of 456 . The exclusion criteria were stroke patient who passed away and consumed herbal medicine which did not given in Dr. Soetomo General Hospital. This research has already received permission eligibility from the ethical committee of Dr. Soetomo General Hospital. Functional status was examined using ordinal scale, Barthel Index score with 10 criteria, such as: feeding, bathing, grooming, dressing, bowels, bladder, using toilet, transfer bed to chair and back, mobility for 45 meters, and using stairs. The data were obtained before and after undergoing the medical rehabilitation. The result was analyzed using Wilcoxon Sign Rank test, included the distribution of each variable.

\section{RESULTS}

The distribution data of Barthel Index score of stroke patients before undergoing medical rehabilitation therapy can be seen from the diagram below.

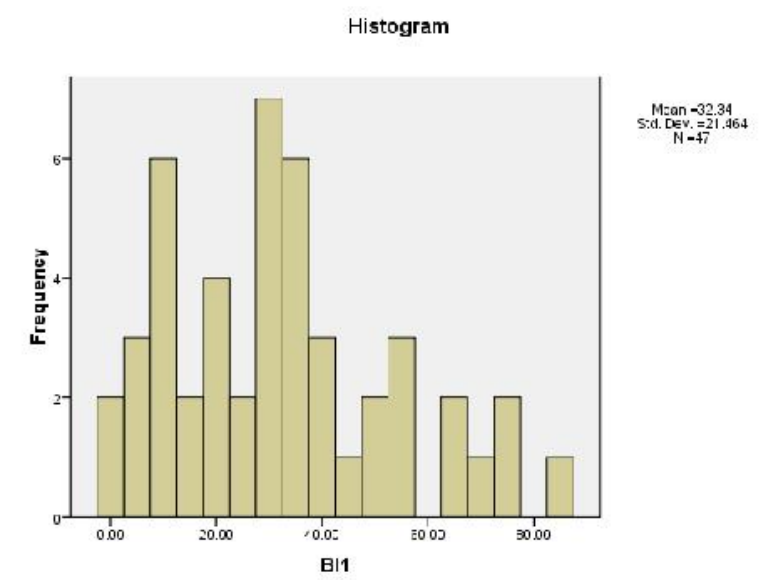

Figure 1. The distribution data of Barthel Index score of stroke patients before undergoing medical rehabilitation

After hospital admission, the stroke patients got the medical rehabilitation by physiotheraphist. However, the frequency of therapy was not determined. It based on the reference of Neurologist for how long they would get the rehabilitation. From Tabel 1 shows the increase in average of Barthel Index score after undergoing the medical rehabilitation.

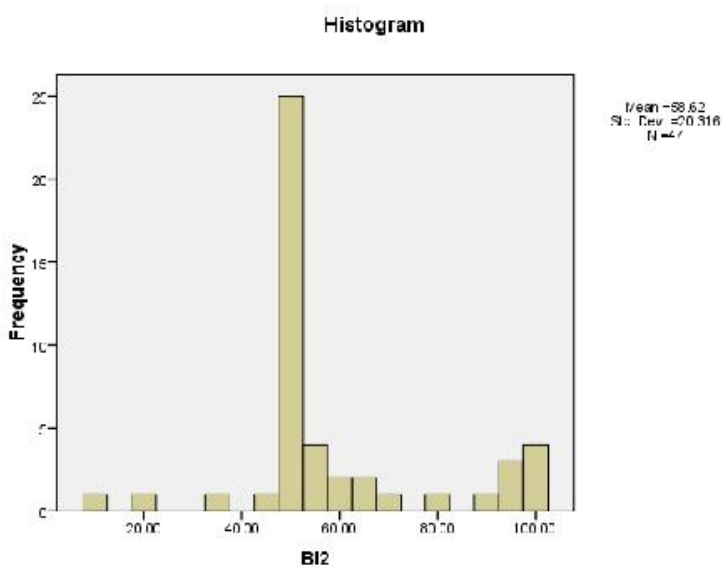

Figure 2. The distribution data of Barthel Index score of stroke patients after undergoing medical rehabilitation

Tabel 1. The comparison between pre and post data

\begin{tabular}{lrr}
\hline & \multicolumn{1}{c}{ BI1 } & \multicolumn{1}{c}{ BI2 } \\
\hline \multicolumn{1}{c}{ Mean } & 32.3404 & 58.6170 \\
Median & 30.0000 & 50.0000 \\
Std. Deviation & 21.46410 & 20.31550 \\
Range & 85.00 & 90.00 \\
Minimum & .00 & 10.00 \\
Maximum & 85.00 & 100.00 \\
\hline
\end{tabular}

\section{DISCUSSION}

This study showed that the average functional status on the first day do physiotherapy was $32.34(\mathrm{SD}=21.46)$, while after medical rehabilitation $58.62(\mathrm{SD}=20.32)$. The average improvement Barthel Index score before and after undergoing the medical rehabilitation was 25.94 to $26.61 \quad(\mathrm{CI}=95 \%)$. Statistical analysis with Wilcoxon Sign Rank test showed the p value of 0.000 $(\alpha<0.05)$, which indicates that there is significant difference of the functional status of stroke patients before and after undergoing medical rehabilitation. Or we can say the therapy was successful. In this case is medical rehabilitation. 
This study strengthens research of Pinzon et al (2009) that medical rehabilitation has an influence on the functional status of patients with stroke. Research of Pinzon et al (2009) showed that the average functional status on the first day do physiotherapy was 20.91 (SD = 4.26), whereas at discharge $65.00(\mathrm{SD}=19.64)$. Statistical analysis showed a significant difference between functional status on the first day with the physiotherapy done at discharge $(\mathrm{P}=0.02)$. However, there are differences between the mean improvement of functional status, functional status improvement research where Pinzon et al (2009) is greater than this study (210.86\% vs. $49.5 \%)$. Smith et al (2007) showed that the increase in functional status as measured at 3 months and 12 months of the greatest in the group receiving intensive therapy, intermediates on the receiving conventional therapy, and the minimum at which no therapy routine in 121 subjects.

Research of Kwakkel et al (2004), a meta-analysis, showed that the addition of time-intensity medical rehabilitation has a small but significant effect on the functional status of patients with stroke, especially if the addition a minimum of 16 hours within the first 6 months. The previous researches above indicate that medical rehabilitation has an effect in improving functional status of stroke patients, especially if it is done intensively in the first 6 months. The more frequent medical rehabilitation, or the greater the intensity of medical rehabilitation time, the greater the improvement of functional status in stroke patients. This reinforces the theory that the activation of neural networks is use-dependent, more it is used, the stronger and more synapses are formed (Bruno-Petrina 2007).

In Bruno-Petrina (2007), the recovery of neurological function after stroke occurs within the first 3-6 months through the natural mechanism of local edema resolution, resorption of toxins - toxin local, local circulation recovery, and recovery of ischemic neurons. The second recovery mechanism is the theory of neuroplasticity through two mechanisms, named colla-teral sprouting and unmasking. Collateral sprouting occurs on intact neurons to perform denervation after most or all inputs are damaged. Unmasking occurs in the neural pathways and synapses which in the normal conditions is not used, but can be activated when a major neuronal system fails.

After doing this study, authors found some weaknesses in this study, such as: First, at the beginning of the study, exposure of medical rehabilitation to each subject is different. Therefore, authors set benchmarks improvement of functional status of stroke patients in this study is the functional status of the subject when the first time they got physiotherapy. However, it still causes a bias in the expected outcome. Second, because of time constraints, the frequency of medical rehabilitation is limited to patients can perform basic activities with assistance. It is probably not optimal for detecting functional status improvement in all subjects because of the degree of the stroke severity each individual is different and there are variations on each individual in terms of recovery time. Third, medical rehabilitation was given on the subject was unspecified, such as: conventional way, PNF, or Bobbath. Medical rehabilitation methods accepted by the subjects is different based on the expertise of a physiotherapist, but the duration of medical rehabilitation was equated. This may affect a large improvement of functional status of stroke patients. However, based on Dickstein et al (1986) on 131 patients with stroke showed that there was no significant difference in terms of improvement of motoric status of the stroke patients in the three methods above. Fourth, the dependent variable measuring instrument using an ordinal scale although frequently used clinically, still has a weaker power than the ratio scale in discriminating against another value. Additionally subjectivity can affect the measurement because it depends on the expertise of data taker. Fifth, this study uses only one sample group (stroke patients treated with medical rehabilitation) without a control group (untreated stroke patients).

\section{CONCLUSION}

There is an increase in Barthel Index score of stroke patients after undergoing medical rehabilitation in Department of Neurology, Dr. Soetomo General Hospital, Surabaya. Stroke patients who get the medical rehabilitation in the ward after stroke attack tend to have a better functional status after they discharge from hospital.

\section{REFERENCES}

Bruno-Petrina A (2007). Motor Recovery in Stroke. Available from http://emedicine.medscape.com/ article/324386-overview. Accessed May 28, 2014

Dickstein R, Hocherman S, Pillar T, Shaham R (1986). Stroke rehabilitation. Three exercise therapy approaches. Phys Ther 66, 1233-1238

Goldstein LB, Bushnell CD, Adams RJ, Appel LJ, Braun LT, Chaturvedi S, Creager MA, Culebras A, Eckel RH, Hart RG, Hinchey JA, Howard VJ, Jauch EC, Levine SR, Meschia JF, Moore WS, Nixon JV, Pearson TA; American Heart Association Stroke Council; Council on Cardiovascular Nursing; Council on Epidemiology and Prevention; Council for High Blood Pressure Research,; Council on Peripheral 
Vascular Disease, and Interdisciplinary Council on Quality of Care and Outcomes Research (2011). Guidelines for the primary prevention of stroke: a guideline for healthcare professionals from the American Heart Association/American Stroke Association. Stroke 42, 517-584

Kusuma Y, Venketasubramanian N, Kiemas LS, Misbach J (2009). Burden of stroke in Indonesia. Int J Stroke 4, 379-380

Kwakkel G, van Peppen R, Wagenaar RC, Wood Dauphinee S, Richards C, Ashburn A, Miller K,
Lincoln N, Partridge C, Wellwood I, Langhorne P (2004). Effects of augmented exercise therapy time after stroke: a meta-analysis. Stroke 35, 2529-2539

Pinzon R, Asanti L, Sugianto, Widyo K (2009). Status fungsional pasien stroke non hemoragik pada saat keluar rumah sakit. Damianus 8, 27-30

Smith WS, English JD, Johnston SC (2007). Cerebrovascular Diseases. In: Fauci AS, Braunwald, E, Kasper DL, Hauser SL, Longo DL, Jameson JL, et al. eds. Harrison's Principle of Internal Medicine. USA: McGraw Hill, 2513-16. 